\title{
Ioan Piuariu-Molnar, Deutsch-Walachische Sprachlebre, Gramatică germano-română, Viena, 1788, vol. I (605 p.), vol. II (559 p.), Editura Universității „Alexandru Ioan Cuza”, Iași, 2018.
}

\author{
Francisc Gafton ${ }^{1}$, Adina Chirilă ${ }^{2 *}$ \\ ${ }^{1}$ Facultatea de Litere, Universitatea „Alexandru Ioan Cuza”, Bd. Carol I 11, 700506 Iasi, România \\ ${ }^{2}$ Facultatea de Litere, Istorie și Teologie, Universitatea de Vest, Bd. Vasile Pârvan 4, 300223 Timişoara, România
}

Este îndeobște recunoscut faptul că o cultură se dezvoltă cu adevărat ca urmare a unui exercițiu conjugat, eminamente rețelar, iar nu ca urmare a activității fragmentate-fie și a unui număr mare de personalităţi exemplare în domeniul lor de activitate. Acest adevăr este necesar a fi nu doar reiterat, ci şi sprijinit faptic prin scoaterea la lumină a realizărilor intelectuale ale societății și prin expunerea lor la o (re)analiză rafinată de perpetue achiziții culturale și cognitive. Se înțelege astfel că edițiile de texte au o importanță crucială pentru cunoaşterea dinamicii unei culturi, în istoricitatea ei. Buna cunoaștere a unui text, a valorilor sale intrinseci și adiacente, a importanței sale pe toate planurile-mijlocită de ediții de text de înalt nivel calitativ—oferă premise de încredere pentru o cercetare care îmbină cunoașterea monografică, de nivel individual, și cuprinderea sintetică, de nivel general.

Demersul editorial se impune cu atît mai mult cu cît materialul de lucru este reprezentat de cărţi care, precum cele ale lui Ioan Piuariu-Molnar, au dat, în momentul scrierii lor, măsura înaltă a valorii umanităţii.

Deși Ioan Piuariu-Molnar este menționat în componentele filologice, gramaticale, de istorie a gramaticilor și de istorie culturală ale lucrărilor de istorie a limbii române literare, conținutul profund al scrierilor sale este relativ puțin cunoscut. În consecință, valoarea și impactul operei acestui învățat transilvănean pentru dezvoltarea culturală românească, în general, sînt încă insuficient recunoscutestare de fapt ce se corectează prin publicarea prezentei ediții critice a gramaticii din 1788 a lui Ioan Piuariu-Molnar.

Scrierea medicului sibian este complexă atît prin concepția şi orînduirea conținutului, cît și din perspectiva scopurilor pe care le vizează. Într-un sens, cele din urmă sînt cît se poate de practice: punerea la dispoziția feluriților factori de limbă germană (funcționari, negustori, călători etc.), care intrau în contact cu românii, a unui instrument care să faciliteze comunicarea și, eventual, să ducă la deprinderea, de către aceia, a limbii române. Din încercarea de a atinge acest scop decurg anumite elemente de concepție a lucrării și de orînduire a conținuturilor ei. De aceea, lucrarea învăţatului iluminist este o gramatică explicată, căreia i se alătură, totodată, un soi de manual de conversație și de redactare a unor texte, ambele-mai cu seamă cel din urmă—orientate către nevoile cititorului avut în vedere.

O primă componentă a lucrării este cea de fonetică și ortografie. Este locul în care se dezvăluie, dintru început, perspectiva practică şi utilitară a scrierii. Scriindu-și textul narativ și explicativ în limba germană, Ioan Piuariu-Molnar „citează”, în chip firesc și adesea, cuvinte românești. Notarea acestora se face în alfabetul chirilic curent, însă cititorul german beneficiază apoi de transcrierea secvențelor în alfabet latin. Totuși, întrucît transcrierea nu îl vizează pe cititorul român, ci pe cel german, ea se face în conformitate cu normele ce decurg din fonetica limbii germane. În felul acesta, cititorul german dobîndește posibilitatea de a avea la îndemînă un instrument de lectură corectă a cuvintelor românești şi de a avea acces la cunoașterea felului în care rostesc românii respectivele secvențe și de a rosti ca atare.

Componenta gramaticală a lucrării cuprinde o parte de morfologie și una de sintaxă. Ambele explică sistemul gramatical al limbii române, în cele două planuri, apoi referitor la clasele lexico-gramaticale și

\footnotetext{
*Adresă de corespondență: chiriladina@yahoo.com.
} 
la categoriile acestora. De aceea se acordă atenție problemelor ce pot apărea în calea vorbitorului nativ al altei limbi (chestiunile legate de gen, număr, flexiune nominală și verbală și chiar de „valeții” acestora), apoi principiilor de formare, recunoaștere și întrebuințare corectă a părților de vorbire și de propoziție, a categoriilor, valorilor și uzurilor lor.

Nivelul lexical-semantic este abordat din perspectiva cîmpurilor lexicale, fapt orientat exclusiv de scopul facilitării pătrunderii nativului german în universul lexical al limbii române. Chiar dacă nu este decît excepțional folosit în cazul limbilor indoeuropene, procedeul este de milenii testat în cazul altor limbi (mai cu seamă asiatice, dar și din Orientul Mijlociu), fiind deosebit de rodnic. În felul acesta, în încercarea de a achiziționa material lexical, nu se mai pleacă de la necunoscut - adică de la niște fluxuri sonore ce trebuie deprinse împreună cu valorile lor generale și specifice-, ci de la cunoscut-adică de la concepte general-umane, grupate în cîmpuri lexicale exprimate în majoritatea limbilor, chiar dacă relativ diferențiate la nivel de note de conținut, de uz și de valori contextuale curente ori preferențiale.

Sub toate aspectele, cele de mai sus indică, pe de o parte, orientarea construcției lucrării către nevoile concrete pe care se presupune a le avea cititorul, de cealaltă, adoptarea unei concepții suple și acomodate la atingerea scopului avut în vedere. Probabil că, sub acest aspect, eficiența unei astfel de paradigme este cît se poate de ridicată, întrecînd alte tipuri de manuale de învățare a unei limbi nematerne.

Dar scrierea învățatului sibian mai vizează un aspect. Este ispita care îl încearcă pe orice autor, fie că scrierea sa este adresată publicului care ar vrea să învețe o limbă străină, fie că se adresează publicului nativ, fie că vizează învățarea, fie că vizează normarea. Cel puțin de la Cantemir încoace, dar mai evident în vremea Școlii Ardelene, învățații poligloți s-au plîns de limba română ca fiind „brudie”. Pe fondul acestui neajuns-firesc pentru orice limbă neexersată, lipsită de aspectul elaborat, proces în urma căruia limba să fi ajuns a fi „lămurită și adusă la regulile gramaticești, apoi și înmulțită cu cuvinte obicinuite la învăţături, care nu se află la vorba de obşte" (Ion BudaiDeleanu) - orice poliglot exersat în lecturile oferite de o cultură și o limbă formate simte inevitabil și irezistibil tentația normării limbii române. De aceea, dincolo de scopul mai sus prezentat, gramatica lui Ioan Piuariu-Molnar este deopotrivă o expresie a strădaniei de a norma limba română, de a o echipa cu modalități proprii unui nivel de expresie adecvat unor nevoi complexe de comunicare. Acestea sînt caracteristici pe care și le însușește orice limbă atunci cînd își creează un aspect ce are a exprima forme și conținuturi științifice și culturale înalte și complexe.

Credem că toate acestea reliefează mai mult gradele și culmile valorice ale Gramaticii lui Ioan Piuariu-Molnar. În primul rînd, acesta construiește o gramatică a limbii române care deține atributele corectitudinii de concepție și de construcție, ale echilibrului prezentării și solicitării cititorului, ale eficienței scopurilor și rezultatelor. În al doilea rînd, toate aceste obiective, dimpreună cu modalitățile lor de împlinire, vădesc faptul că învățatul sibian înțelege că edificiile trainice au nevoie nu doar de temelii solide, dar și de acțiune conjugată, în cadrele unei culturi-oricît de incipiente sau de brudii ar fi ea.

Parcurgînd cu stăruință calea împovărătoare, dată de înțelegerea importanței cruciale a unor astfel de ediții de text, autorii ediţiei, Ana-Maria Minuț și Ion Lihaciu, și-au asumat marea responsabilitate de a întocmi o ediție pe care să o doteze cu necesarul aparat critic. Fiind lucrarea lui Ioan Piuariu-Molnar foarte întinsă—adică îndelung solicitantă—și foarte complexă—adică solicitînd în felurite chipuri și intensități-, o ediție critică la Gramatică germanoromână avea de răspuns la variate cerințe imperioase.

Din pricina dimensiunilor cărții (540 p., ediția Kurzbek, Viena,1788), ediția critică de față a trebuit să fie structurată în două volume ce cuprind, din substanța ediției princeps a operei lui Ioan PiuariuMolnar: vol. I: Partea I. Despre ortografie și o parte din Partea a II-a. Cercetarea cuvintelor (Etymologia); și vol. II: a doua parte din Etymologia, Partea a III-a. Despre sintaxă, Culegere de cuvinte românești și germane, Nişte dialoguri, pentru a cuvînta despre multe feliuri de stări inainte, Niște povestiri, Stil trebnicesc, cărți și alte însămnări aseaminea și Indice de cuvinte germane. Facsimilele textului de bază sînt prezentate în contrapagina versiunii editate, urmînd riguros structura și conţinutul paginilor originare. În felul acesta, specialistul poate cuprinde comod ambele ipostaze ale lucrării, desfășurîndu-și, eventual—trecînd dincolo de ceea ce oferă ediția ca rezultat al unui remarcabil, deja, efort analitic-, propriile cercetări asupra textului.

Fiind o carte de învățare a limbii române prin 
intermediul germanei, cu terminologie, explicaţii și corespondențe lexicale şi discursive în această limbă și, în cazul primei componente menționate, și în latină, a fost necesar ca editorii să realizeze o traducere a acestor părți, recurgînd însă la păstrarea codului străin în două situații: prima este cea reprezentată de termenii de specialitate, care rămîn redați în limba latină (respectîndu-se însă regulile de recțiune din română, I, p. 10, 72), dacă în textul lui Molnar apar astfel. Decizia editorială pune în evidență, implicit, preocuparea curentă în epocă, la care aderă autorul gramaticii, de a fixa în știința limbii o terminologie gramaticală modernă și unitară, a cărei garanție de corectitudine și claritate rămîne latina. A doua situație care impune păstrarea codului lingvistic străin este cea a corespondențelor lexicale germane, prezente ca atare în ediția critică a textului, eventual într-o formă corectată, dacă în varianta originară s-au constat erori formale. În acest caz, editorii au oferit în notele explicative detalii despre forma existentă în ediția princeps și în edițiile ulterioare. În situația constatării unor inadvertențe semantice, corectura nu se operează în text, ci ia forma unor lămuriri emendatoare în note.

Componenta românească a gramaticii apare în textul lui Molnar în ipostază dublă: ca expresie grafică a elementelor de gramatică, vocabular și discurs prezentate, redată în alfabet chirilic; şi ca imagine sonoră a acestor elemente (excepție fac istorioarele din Nişte povestiri și scrisorile din Stil trebnicesc, cărți și alte însemnări aseaminea), redată cu litere latine, după ortografia germană, și care avea scopul de a-1 "ghida întrucîtva” pe utilizatorul german în privința pronunției românești (v. Vorrede/Prefață, p. 85). Autorii ediției nu intervin substanțial asupra reprezentării ipostazei a doua, rezumîndu-se la a plasa „transcrierile fonetice” operate de Ioan PiuariuMolnar între paranteze drepte şi păstrînd întrutotul corespondențele (e.g., rom.chir. $\boldsymbol{\omega} / \mathrm{f} /$ - germ. [sch] / /; rom.chir. ц /ts/ - germ. [z] /ts/; rom.chir. $\mathbf{x} / \hat{\mathbf{1}} /$ - $\overline{\mathfrak{x}}$; etc.) create de autor. Este unica soluție editorială pertinentă și utilă cercetătorilor, în această situație, întrucît ea redă cu acuratețe concepția autorului, potrivit scopurilor vizate de acesta, și, totodată, coerența sistemului ortografic cu litere latine propus implicit de Molnar.

Secvențele scrise în limba română cu alfabet chirilic sînt transcrise interpretativ cu alfabet latin, în acord cu normele filologice actuale și cu caracte- risticile textului (asupra cărora autorul chiar insistă uneori). Se conturează astfel un aparat și un sistem de transcriere particulare, care servesc exemplar textul, văzut ca produs intelectual al unui context specific, cu justificări și scopuri ce ar putea scăpa observației dacă procesul editorial s-ar mulțumi cu aplicarea procustiană a cutumelor, fie ele și îndreptăţite, în general, și îndelung exersate. Ingenioasă este, sub acest aspect, opțiunea de a reda diftongul /ie/ cu ajutorul unui $e \mathrm{cu}$ ison, precum în textul de bază (I, p. 14); ori aceea de a marca prin $i$ ceea ce apare ca fenomen de fonetică dialectală ce acoperă de fapt existența structurii de adîncime "pronume + forma (populară) $-i$ a verbului a fi" (I, p. 15), în, e.g., „МЪнЖнк КХнА ми фоаме / mănînc cînd mi foame [me'n̄̄nk kǣnd mi foame]. Ich esse wenn ich bungrig bin." (II, p. 371) (cf. însă II, p. 229, unde ingenioasa soluție grafică nu este aplicată); etc.

Răspunsurile editoriale la solicitările de acest tip ale textului sînt documentate pe larg în Studiu introductiv (I, p. 7-70) și sint reluate, pe scurt, în Notă asupra ediției (I, p. 71-73). Dar, în afara acestor explicații, autorii ediției aduc în capitolul introductiv pe care îl semnează cîteva precizări valoroase din punct de vedere cultural-istoric și lingvistic.

Ana-Maria Minuț și Ion Lihaciu amintesc, mai întîi, în mod necesar, de cadrul general în care, după mijlocul secolului XVIII, acțiunile unui număr însemnat de intelectuali transilvăneni erau subordonate exclusiv ambiției de a genera și a susține un curent de emancipare a românilor și de modernizare a societății. Acesta urma să includă dezvoltarea limbii-ca instrument de cizelare și ca oglindire a esenței spirituale a națiunii, dar și ca mijloc prin care valoarea națiunii este afirmată și se face cunoscută altora. Este vorba, în fapt, de manifestări comune în Europa luminilor, străbătută de idei care, lăsînd la o parte disputa privind originea și natura limbilor, conturau (prin John Locke, deja de la sfîrșitul secolului XVII, sau James Harris, ori Johann Herder) o teorie lingvistică ce viza nu atît limba în sine, cît condiția umană (și cea a unui popor) reflectată în limbă. În legătură cu faptul sincronizării preocupărilor identitar-lingvistice ale umaniștilor europeni este deosebit de importantă informația nouă (I, p. 11-12; pentru demonstrație, v. passim) că gramatica lui Ioan Piuariu-Molnar urmează, pe lîngă modelul gramaticii românești din 1780 a lui Samuil Micu și Gheorghe Șincai, Elementa 
lingux daco-romane sive valachice, și modelul unor gramatici-manual străine, cu germana ca limbă ce intermediază achiziția lingvistică. Este vorba de gramatică lui J.R. des Pepliers, Nouvelle et parfaite grammaire royale françoise et allemande. Neue und vollständige königliche französische Grammatik..., și de gramatica lui Hilmar Curas, Erleichterte und durch lange Erfahrung verbesserte französische Grammatik-lucrări ce îi furnizează învățatului român opțiuni privind organizarea internă a capitolelor, indicarea corespondentelor în limba germană ale cuvintelor, formularea explicațiilor, comentariilor sau recomandărilor gramaticale (I, p. 11-12).

La fel de importantă pentru indicarea anvergurii preocupărilor cultural-lingvistice din epocă și, concomitent, pentru cuprinderea valorii cărții lui Ioan Piuariu-Molnar o constituie evidențierea de către editori a demersurilor de reeditare a ei, în 1810 și 1823 (la Sibiu); apoi, a textelor de întîmpinare a cărții în mediul german, publicate în presa din Viena și Jena (I, p. 67); în sfîrșit, a calității gramaticii de sursă bibliografică, și model pentru lucrări cu caracter lingvistic și alte cărți de normare și/sau învățare a limbii române (I, p. 20, 22 etc.; 67-68).

Descrierea și comentariul editorilor asupra cărții lui Ioan Piuariu-Molnar, în privința compartimentelor limbii-cf. subcapitolele respective ale studiului introductiv, care urmează îndeaproape structura lucrării originare: Despre ortografie (I, p. 12-19), Despre cercetarea cuvintelor (Etymologia) (I, p. 19-
42), Despre sintaxă (I, p. 42-47), Culegere de cuvinte românești și germane (I, p. 47-61)-, cuprind fine observații ce reușesc să pună în lumină potențiala forță normativă (relevantă deci în chestiunea constituirii aspectului modern al românei literare) a acestui-în primul rînd-instrument de învățare a unei limbi străine, al cărui public-țintă nu are, totuși, a se pronunța asupra regularității, corectitudinii, eficienței şi caracterului îngrijit ale acesteia. Acest rezultat este dat de comparația pe care editorii o realizează, frecvent și minuţios, între gramatica lui Molnar și gramatica lui Micu și Șincai.

În sfîrșit, observăm că-în conformitate cu uzanțele și exigențele filologice-existența celor trei ediții ale gramaticii învăţatului ardelean i-a determinat pe realizatorii prezentei ediţii critice să le parcurgă în paralel-luînd ca text de bază ediția princeps, din 1788_și să semnaleze în subsolul paginilor inerentele și numeroasele, dar relativ nesemnificativele diferențe formale și de conținut dintre acestea.

Punînd în act numeroase și profunde cunoștințe de filologie, de lingvistică diacronică și sincronică și de istorie culturală, cei doi autori ai ediției critice a Gramaticii germano-române a lui Ioan Piuariu-Molnar au sublimat întreaga lor trudă sub forma lămurită a unei opere editoriale care constituie un bun științific şi cultural cîștigat, în măsură să servească drept pildă și învăţătură. 